\title{
AMv
}

\section{Calming the Storm: A review of corticosteroid use in severely ill COVID-19 patients on mechanical ventilation}

Tran Dinh BSB/HS ${ }^{1}$, Cherie Chu PharmD ${ }^{2}$

DOI: https://doi.org/10.53097/JMV.10036

Cite: Dinh T, Chu C. Comparison of Systemic Corticosteroids used in Hospitalized Severely Ill Mechanically Ventilated Covid-19 patients. J Mech Vent 2021; 2(4):132-141.

\begin{abstract}
:
The importance of corticosteroids in the therapy of COVID-19 has been controversial. However, as the world develops a better understanding regarding the pathophysiology of COVID-19, we are realizing that suppressing the host immune response may reduce lung inflammation preventing further complications. In addition, more high-quality randomized controlled trials, meta-analysis, and review articles are being published discussing the role of corticosteroids. Majority of these studies concluded that corticosteroids are beneficial for hospitalized severely ill COVID-19 patients requiring supplemental oxygen.
\end{abstract}

To date, therapeutic guidelines for COVID-19 patients recommend dexamethasone or other alternative corticosteroids, including methylprednisolone, hydrocortisone, or prednisone, as a treatment choice for severely ill COVID-19 patients.

This review will discuss the pharmacology, mechanism of action, pharmacodynamics, pharmacokinetics, and benefits of corticosteroids in COVID-19 patients, and review current published clinical evidence on corticosteroids.

Keywords: Corticosteroids, COVID-19, ARDS

\section{Authors}

1. Tran Dinh Student pharmacist University of Hawaii at Hilo Daniel K. Inouye College of Pharmacy

2. Cherie Chu PharmD, BCCCP Associate professor University of Hawaii at Hilo Daniel K. Inouye College of Pharmacy, Hawaii, USA

Corresponding author: trandinh@hawaii.edu

Conflict of interest/Disclosures: None

Funding: None 
Dinh T Calming the Storm: A review of corticosteroid use in severely ill COVID-19 patients on mechanical ventilation

\section{Introduction}

Corticosteroids have been used in the treatment of COVID-19, since the beginning of the pandemic, due to their antiinflammatory effects and on the host immune system. It is postulated that they may help severely ill mechanically ventilated COVID-19 patients, at risk of developing lung inflammation which can lead to lung injury and multisystem organ dysfunction. The use of corticosteroids may have clinical benefits for these patients. ${ }^{1}$

The World Health Organization (WHO) recommends systemic corticosteroids for the treatment of patients with severe and critical COVID-19. ${ }^{2}$ The criteria include patients with COVID-19 needing mechanical ventilation (invasive or noninvasive) and who are at risk for serious complications such as severe pneumonia, acute respiratory distress syndrome (ARDS), cytokine storm syndrome, and even death.

In addition, the COVID-19 Treatment Guidelines Panel ${ }^{1}$ recommends the use of dexamethasone or other systemic corticosteroids for hospitalized adults with COVID-19, including patients who are hospitalized and require supplemental oxygen, oxygen delivery through a high flow device, non-invasive ventilation, or invasive mechanical ventilation (IMV) and Extra Corporeal Membrane Oxygenation (ECMO). If dexamethasone is not available, alternative glucocorticoids (e.g., prednisone, methylprednisolone, hydrocortisone) can be used.

Data from randomized controlled trials, high-quality systematic reviews, and meta-analyses strongly support using corticosteroids in patients with COVID-19 that require oxygen support. Suppression of the overwhelming systemic inflammation, by corticosteroids, can help with the inflammatory process in oxygen-dependent or severe COVID19 patients. $^{2}$

Therapeutically, corticosteroids are immunomodulatory drugs that help prevent and attenuate the severe hyper-inflammation process in severe COVID-19 infections. This process occurs in both tissue and systemic circulation via non-genomic and genomic effects. ${ }^{3}$ Corticosteroids may be administered intravenously (IV) or orally in severely ill patients. ${ }^{2,3}$ Most literature recommends the use of dexamethasone $6 \mathrm{mg}$ daily for up to 10 days or an equivalent dose of hydrocortisone 50 mg every 8 hours, prednisone $40 \mathrm{mg}$ daily, or methylprednisolone $32 \mathrm{mg}$ daily ( $8 \mathrm{mg}$ every 6 hours or $16 \mathrm{mg}$ every 12 hours). ${ }^{1,2}$

Corticosteroids have been studied extensively in ARDS patients ${ }^{3}$ and are recommended in patients with persistent or refractory moderate to severe disease, who have refractory sepsis or community-acquired pneumonia.
The anti-inflammatory, antifibrotic and vasoconstrictive effects of corticosteroids have been reported to improve outcomes in patients with ARDS. ${ }^{4}$

Common recommended corticosteroid regimens for ARDS include methylprednisolone $1 \mathrm{mg} / \mathrm{kg}$ per day for 21 to 28 days or dexamethasone $20 \mathrm{mg}$ IV once daily for five days, tapering to $10 \mathrm{mg}$ once daily for five days. This dosing is supported by a study by Villar and colleagues, ${ }^{5}$ which found that use of high dose dexamethasone in moderate to severe ARDS patients had lower 60-day all-cause mortality compared to those who received standard intensive care $(21 \%$ vs. $36 \%$, P 0.005 ). The primary outcome resulted in the dexamethasone group had a larger mean number of ventilator-free days than patients in the control group (mean 12.3 vs 7.5 days); between-groups difference 4.8 days [ $95 \%$ CI 2.57-7.03] $\mathrm{P}$ $<0 \cdot 0001$. The treatment with dexamethasone had more ventilator-free days.

\section{Mechanism of Corticosteroids}

The development of severe COVID-19 is dominated by inflammatory infiltrates, diffuse alveolar damage, microvascular thrombosis, and inflammatory organ injury mediated by the host immune responses. Studies have shown that oxygen-dependent COVID-19 patients have increased acute phase reactants such as $\mathrm{C}$-reactive protein and serum amyloid A.

The process of excessive immune system dysregulation and increased pulmonary endothelial and epithelial permeability leads to lung damage and the release of pro-inflammatory cytokines. ${ }^{6}$ Essentially, the steroid molecule binds to glucocorticoid receptors stimulating the synthesis and release of anti-inflammatory proteins.

These agents inhibit transcription factors that control proinflammatory mediators such as dendritic cells, mast cells, macrophages, eosinophils, and lymphocytes. Furthermore, corticosteroids inhibit phospholipase A2, an essential factor in the production of various inflammatory mediators.

This prompts the use of corticosteroids as a treatment option which helps modulate and reduce the progress of inflammation and organ failure in hospitalized patients. ${ }^{3,7}$

Figure 1 depicts the mechanism of action of corticosteroids. Generally speaking, these drugs function as agonists at the glucocorticoid receptors and/or mineralocorticoid receptors. They are classified according to hypothalamic-pituitaryadrenal (HPA) axis suppression, mineralocorticoid activity, and potency. 
Corticosteroids enter the cell to the cytoplasm and bind to the glucocorticoid receptors (GR) which is complex with heatshock protein (hsp90). It then translocates to the nucleus where it binds to a glucocorticoid recognition element (GRE) on the $5^{\prime}$-upstream promoter sequences of steroid-responsive genes. The positive GRE transactivation will promote antiinflammatory mediators while negative GRE will suppress proinflammatory mediators. Corticosteroids also bind to membrane-bound GR (mGR) where non-genomic effects occur. ${ }^{8}$

\section{Pharmacokinetics and Pharmacodynamics of Corticosteroids}

Due to the intracellular mechanism of action of corticosteroids, the onset of systemic corticosteroids is delayed by 3-8 hours regardless of route of administration. Due to this unique intracellular mechanism, corticosteroid duration of effect does not correlate with their duration of action. Structural modifications to the steroids can increase potency and reduce mineralocorticoid effects. ${ }^{8}$ Both potency and mineralocorticoid activity of corticosteroids are relative to hydrocortisone. ${ }^{7}$

The classification of corticosteroids is broken down into short, medium, or long acting based on the duration of action on the HPA axis. Table 1 compares various corticosteroids with respect to their pharmacokinetic and pharmacodynamic profiles and potency.

Contrasting between dexamethasone and methylprednisolone, dexamethasone is a pure glucocorticoid that affects the transcription of cytokines and glucocorticoid-induced gene transcriptions. It has higher potency due to its higher affinity for glucocorticoid receptors, however, that lacks mineralocorticoid stimulation which has minimal effect on sodium balance and fluid volume. ${ }^{67}$ Furthermore, dexamethasone is a long-acting corticosteroid with a half-life of 36-72 hours, making it effective for daily dosing compared to hydrocortisone, which has equal affinity glucocorticoid and mineralocorticoid receptors. ${ }^{9}$ Thus its properties make it beneficial for managing septic shock in patients with COVID19. ${ }^{10}$

Interestingly, methylprednisolone has been the preferred agent for corticosteroids therapy by many physicians since it achieves higher lung tissue to plasma ratios in animal models than dexamethasone, which works more efficiently for lung injury. ${ }^{10}$

In a study by Ranjbar and colleagues ${ }^{11}$ which was a tripleblinded randomized controlled trial that included 86 patients hospitalized with COVID-19. This study compared the use of methylprednisolone $2 \mathrm{mg} / \mathrm{kg} /$ day or dexamethasone $6 \mathrm{mg} /$ day. The mortality rates and length of hospital stay were lower in patients who received methylprednisolone.

In another study by Pinzón and colleagues, ${ }^{12} 216$ severely ill COVID19 pneumonia patients were given methylprednisolone 250 to $500 \mathrm{mg}$ IV daily for three days, followed by prednisone $50 \mathrm{mg}$ orally every day for 14 days or dexamethasone $6 \mathrm{mg} \mathrm{IV}$ daily. After completing four days of treatment, the paraclinical markers, including C-reactive protein, d-dimers, and lactate dehydrogenase, were significantly lower in the methylprednisolone group. As concluded, the mortality rate was lower in the group receiving methylprednisolone.

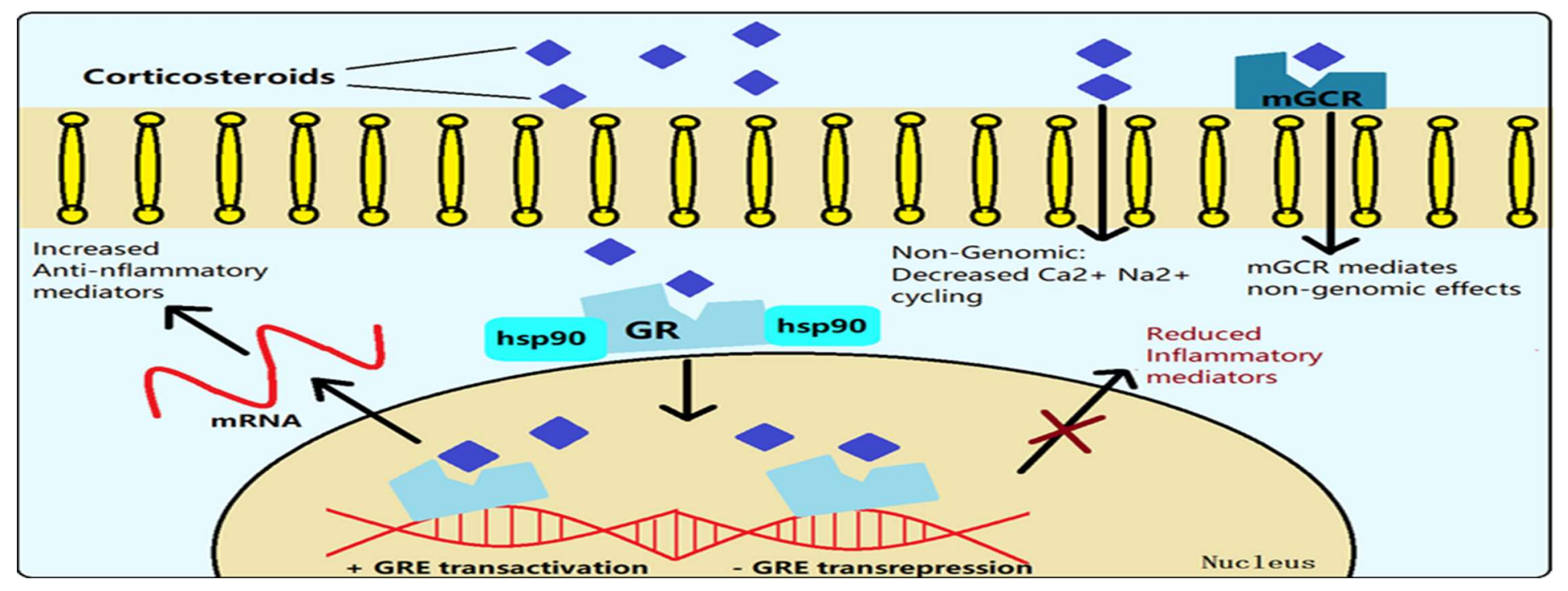

Figure 1 The mechanism of action of corticosteroids with glucoid response elements (GRE) and other non-genomic effect 
Dinh T Calming the Storm: A review of corticosteroid use in severely ill COVID-19 patients on mechanical ventilation

\begin{tabular}{|c|c|c|c|c|c|c|c|}
\hline Medication & Structure & $\begin{array}{l}\text { Mineralocortic } \\
\text { oid activity } \\
\text { (Potency } \\
\text { relative to } \\
\text { hydrocortisone } \\
\text { ) }\end{array}$ & $\begin{array}{c}\text { Anti- } \\
\text { inflammatory } \\
\text { (Potency } \\
\text { relative to } \\
\text { hydrocortison } \\
\text { e) }\end{array}$ & $\begin{array}{c}\text { Duration } \\
\text { of action } \\
\text { (Hours) }\end{array}$ & $\begin{array}{c}\text { Onset } \\
\text { (Hours) }\end{array}$ & $\begin{array}{l}\text { Half-Life } \\
\text { (Hours) }\end{array}$ & $\begin{array}{c}\text { Equivalent } \\
\text { glucocorticoid } \\
\text { dose } \\
(\mathbf{m g})\end{array}$ \\
\hline \multicolumn{8}{|c|}{ Short Acting } \\
\hline Hydrocortisone & & 1 & 1 & $8-12$ & 1 & $\begin{array}{l}\text { IV: } 2 \pm 0.3 \\
\text { hours; } \\
\text { Oral: } 1.8 \pm \\
0.5 \text { hours }\end{array}$ & 20 \\
\hline \multicolumn{8}{|c|}{ Intermediate Acting } \\
\hline Prednisone & & 0.8 & 4 & $12-36$ & $\begin{array}{c}\text { Acute } \\
\text { (minutes } \\
\text { after } \\
\text { administra } \\
\text { tion) } \\
\text { and/or } \\
\text { chronic (2 } \\
\text { to } 20 \\
\text { hours to } \\
\text { days) }\end{array}$ & $\begin{array}{c}2.1-3.5 \\
\text { hours }\end{array}$ & 5 \\
\hline $\begin{array}{l}\text { Methylprednisol } \\
\text { one }\end{array}$ & & 0.5 & 5 & $12-36$ & $\begin{array}{c}\text { IV } \\
\text { (succinate) } \\
\text { : Within } 1 \\
\text { hour }\end{array}$ & $\begin{array}{c}\text { Oral: } 2.5 \pm \\
1.2 \text { hours } \\
\text { IV } \\
\text { (succinate) } \\
: 0.25 \pm \\
0.1 \text { hour }\end{array}$ & 4 \\
\hline \multicolumn{8}{|c|}{ Long Acting } \\
\hline Dexamethasone & & 0 & 30 & $36-54$ & 1 hour & $\begin{array}{c}\text { Oral: } 4 \pm \\
0.9 \text { hours } \\
\text { IV: } \sim 1 \text { to } 5 \\
\text { hours }\end{array}$ & 0.75 \\
\hline
\end{tabular}

Table 1 Corticosteroid comparison chart 
Dinh T Calming the Storm: A review of corticosteroid use in severely ill COVID-19 patients on mechanical ventilation

\section{Corticosteroids Dosing for severe COVID-19}

The National Institute of Health recommends dexamethasone for hospitalized patients requiring mechanical ventilation oral or IV $6 \mathrm{mg}$ once daily for up to 10 days, alternative options including methylprednisolone $32 \mathrm{mg}$ daily as a single dose or 2 divided doses, hydrocortisone $50 \mathrm{mg}$ every 8 hours, or 40 mg of prednisone daily. ${ }^{1}$

Although many guidelines recommend the previously noted standard dose of dexamethasone for critically ill COVID-19 patients, questions remain if a higher dose may benefit those with more complications due to COVID-19.

The dose of dexamethasone $6 \mathrm{mg} /$ day for ten days is considered low, compared to its use in a trial done by Tomazini and colleagues (CoDEX) randomized trial ${ }^{13}$ in patients with moderate to severe ARDS, in which the dose of dexamethasone was $20 \mathrm{mg}$ of dexamethasone IV daily for five days, then and $10 \mathrm{mg}$ daily for five days or until ICU discharge was used.

A study by Fernandez-Cruz and colleagues ${ }^{14}$ concluded that an initial regimen of methylprednisolone $1 \mathrm{mg} / \mathrm{kg} /$ day of resulted in lower hospital mortalities in COVID-19 patients with pneumonia.

Another randomized clinical trial by Munch and colleagues ${ }^{15}$ completed at 26 hospitals in Europe and India assessed the effects of dexamethasone $12 \mathrm{mg} /$ day versus $6 \mathrm{mg}$ /day in patients with COVID-19 and severe hypoxemia. Notably, the mortality at 28 days was $27.1 \%$ and $32.3 \%$, respectively which was not significantly different. The study also showed that there were no significant differences in days alive without life support at 28 days between the two groups.

Additionally, a meta-analysis from the WHO Rapid Evidence Appraisal for COVID-19 Therapies (REACT) Working Group ${ }^{16}$ evaluated the daily glucocorticoid equivalent doses ranging from $6 \mathrm{mg}$ to $20 \mathrm{mg}$. No differences were observed between the low versus high doses administered. Further trials will need to be conducted to compare the recommended dose to a higher dose.

Contrastingly, a pre-planned, secondary Bayesian analysis of the COVID STEROID 2 trial completed by Granholm and colleagues ${ }^{17}$ found high probabilities of benefit and relatively low probabilities of clinically significant harm with dexamethasone $12 \mathrm{mg}$ versus $6 \mathrm{mg}$ daily for up to 10 days in patients with COVID-19 and severe hypoxemia. The trial was an international, centrally randomized, parallel-group blinded with the inclusion of patients hospitalized with COVID-19 and severe hypoxemia, independent of the delivery system and use of noninvasive ventilation or continuous positive airway pressure or invasive mechanical ventilation. Patients were randomized to dexamethasone $12 \mathrm{mg}$ or $6 \mathrm{mg}$ IV for a maximum of 10 days. The primary outcome analyzed the days alive without life support at day 28 , defined as days alive without invasive mechanical ventilation circulatory support and kidney replacement therapy. The data showed an adjusted mean difference of 1.3 days and an adjusted incidence rate ratio of 1.08 with the probabilities of any benefit at $94.2 \%$ and clinically important benefits at $63.9 \%$ with $12 \mathrm{mg}$ dexamethasone group at days alive without life support at day 28. The data concluded that there were high probabilities of benefits with $12 \mathrm{mg}$ of dexamethasone in comparison with the current recommended dose of $6 \mathrm{mg}$.

\section{Obesity Dosing of Corticosteroids}

Aside from the questions on optimal dosing of corticosteroids in COVID-19 patients, the question of dosing in obesity also remains a debatable topic. The use of ideal or adjusted body weight is suggested for weight-based dosing in obese patients. ${ }^{18}$

Previous trials have shown that the volume of distribution of corticosteroids is closely related to ideal body weight suggesting limited distribution into adipose tissues, resulting in changes of pharmacokinetic and pharmacodynamic profiles of corticosteroids. ${ }^{19}$

A study by Dunn and colleagues ${ }^{19}$ suggests that a weightbased dose of $0.6 \mathrm{mg} / \mathrm{kg}$ IV daily, moderately obese patients with IBW over at least $35 \%$. However, the use of an ideal or adjusted weight is suggested for weight-based dosing in obese patients with BMI of $40 \mathrm{~kg} / \mathrm{m} 2$ or greater is recommend for methylprednisolone for patients with ARDS. ${ }^{20}$ Regardless, the dosing of corticosteroids should be adjusted based on patientspecific factors. ${ }^{13}$

\section{Comparison of literature supporting the use of corticosteroids in severely ill mechanically ventilated COVID-19 patients being treated with corticosteroids}

Recognizing the importance of corticosteroids in treating COVID-19, the research and investigation of corticosteroids for severe COVID-19 patients launched worldwide. As the number of critically ill patients increased, the priority of these trials is to help guide management and treatment of severely ill COVID-19 patients. The following are overview summaries of clinical studies supporting the use of various corticosteroids in the treatment of severe COVID-19 infection. These results are also summarized in Table 2. 
Dinh T Calming the Storm: A review of corticosteroid use in severely ill COVID-19 patients on mechanical ventilation

\section{REACT}

A prospective meta-analysis of 7 randomized clinical trials that included 1,703 critically ill patients from 12 different countries. ${ }^{16}$

The trial randomized patients to receive systemic corticosteroids, including dexamethasone, hydrocortisone, or methylprednisolone in comparison to patients receiving standard care or placebo. According to the study, there were 222 deaths among 678 patients randomized to receive systemic dexamethasone, hydrocortisone, or methylprednisolone and 425 deaths among 1025 patients randomized to usual care or placebo. The data resulted in an OR of 0.66 (95\% CI, 0.53-0.82; P < 0.001) for all-cause mortality comparing corticosteroids with usual care or placebo.

The administration of systemic corticosteroids in severely ill patients with COVID-19 was associated with lower 28 days all-cause mortality compared to standard care.

\section{Recovery Trial}

A large open-label randomized control study known as the RECOVERY trial from the UK-based designed to evaluate the effects of dexamethasone treatment compared to usual care provided to hospitalize patients who were receiving oxygen without invasive mechanical ventilation. ${ }^{6}$ The trial enrolled 6425 patients with 2104 randomized to receive dexamethasone and 4321 randomized to receive usual care.

The treatment with dexamethasone $6 \mathrm{mg} / \mathrm{d}$ for 10 days resulted in reducing mortality by one third in patients receiving mechanical ventilated $(29.3 \%$ vs $41.4 \%$, rate ratio 0.64 ) and by one fifth in patients receiving supplemental oxygen ( $23.3 \%$ vs $26.2 \%$, rate ratio 0.81$)$ in comparison to usual care alone. One key difference from this trial was that there was no benefit of using corticosteroids among patients who are not on respiratory support.

Overall, the results from the RECOVERY trial demonstrated that among hospitalized patients with Covid-19, the use of dexamethasone for up to 10 days helped lower the 28-day mortality rate.

\section{CoDEX}

A multicenter, randomized open-label trial conducted in 41 intensive care units, in Brazil, on patients with moderate to severe ARDS secondary to COVID-19. ${ }^{13}$

The primary objective was to investigate the use of intravenous dexamethasone plus standard care in comparison to standard care alone. Patients were randomized by a 1:1 ratio to receive dexamethasone $20 \mathrm{mg} \mathrm{IV}$ once daily for five days, then $10 \mathrm{mg}$ IV once daily for an additional five days or until discharge from the ICU plus standard care, or standard care alone.

The mean number of days alive and free from mechanical ventilation during the first 28 days was significantly higher in the dexamethasone group than in the standard care group (6.6 days $95 \%$ CI, 5.0-8.2 days vs 4.0 days $95 \%$ CI, 2.9-5.4 days with $95 \% \mathrm{CI}, 0.2-4.38, \mathrm{P}=.04)$. The 28 -day mortality in the corticosteroid group was $85 / 151(56.3 \%)$ versus $91 / 148$ in the no corticosteroids group $(61.5 \%$ with hazard ratio, $0.97 ; 95 \%$ CI, 0.72 to $1.31 ; \mathrm{P} 0.85$ ). The number of days alive and days free from mechanical ventilation at 28 days was lower for the dexamethasone plus standard care group compared to standard care alone group. This study supported that dexamethasone may be used to attenuate lung injury in patients with COVID19 associated ARDS. However, in contrast with the RECOVERY trial, the mortality rates were higher in the CoDEX trial.

\section{REMAP-CAP}

A multicenter, multinational, randomized trial that included 403 patients with severe COVID-19 on respiratory or cardiovascular support. ${ }^{21}$ Patients were randomized into three groups: fixed low-dose hydrocortisone, shock-dependent hydrocortisone, or no hydrocortisone. The clinical trial provides evidence that the treatment with hydrocortisone resulted in $93 \%$ and $80 \%$ probabilities of superiority regarding improvement in organ support-free days within 21 days compared with no hydrocortisone. The primary outcome of 28-day mortality was 78/278 in the corticosteroid versus $33 / 99$ in the no corticosteroids group and the RR was $0.84(95 \% \mathrm{CI}$ : $0.60-1.18)$.

However, the trial was stopped early, and no treatment strategy met prespecified criteria for statistical superiority, precluding definitive conclusions.

\section{MetCOVID}

A randomized, parallel, double-blind, placebo-controlled study in Brazil conducted among those who had clinical and/or radiological suspicion of COVID-19 and either had $\mathrm{SpO} 2 \leq 94 \%$ with room air, required supplementary oxygen, or required IMV. ${ }^{22}$

This study was aimed to evaluate the efficacy of methylprednisolone among hospitalized patients. Patients were randomized in a $1: 1$ ratio to receive either methylprednisolone $0.5 \mathrm{mg} / \mathrm{kg}$ IV or placebo twice daily for five days. The primary outcome was 28 -day mortality. There were 416 patients randomized, with 194 and 199 individuals 
assigned to methylprednisolone and placebo groups, respectively.

The study showed no significant differences between the two groups, with an overall 28 -day mortality of $38.2 \%$ in the placebo group versus $37.1 \%$ in the methylprednisolone group and OR 0.91 (95\% Cl 0.29-2.87). However, there was a reduced mortality rate in patients receiving steroids in patients aged over 60 years old. No evidence regarding improvement in survival in the group receiving short course intravenous MP was reported.

\section{Mixed Results Studies}

In contrast to studies supporting the use of corticosteroids in COVID-19 patients, there are also studies showing mixed results.
A study conducted by Albani and colleagues ${ }^{23}$ concluded that treatment with corticosteroids did not affect hospital mortality in patients with COVID-19.

The results showed that 171 patients died (30.6\%) with corticosteroids, and 183 patients died (21.7\%) without corticosteroid treatment.

Additionally, a randomized trial done by Jeronimo and colleagues ${ }^{22}$ looking at methylprednisolone use, resulted in a 28-day mortality of 76/199 (38.2\%) in the placebo group versus $72 / 194$ (37.1\%) in the methylprednisolone group (P $0.629)$ group showing no difference in mortality between the two groups. The results from this study provide no support for corticosteroids in improving the survival rate for hospitalized COVID-19 patients.

\begin{tabular}{|c|c|c|c|c|c|c|c|}
\hline Studies & $\begin{array}{c}\text { Design } \\
\text { Location }\end{array}$ & $\begin{array}{l}\text { Eligibility } \\
\text { Criteria }\end{array}$ & $\begin{array}{l}\text { Population } \\
\text { Actual (n) }\end{array}$ & $\begin{array}{l}\text { Corticosteroid } \\
\text { (Drug Name) }\end{array}$ & $\begin{array}{l}\text { Dose/ route/ } \\
\text { frequency }\end{array}$ & Duration & $\begin{array}{l}\text { Primary outcome } \\
\text { with statistics }\end{array}$ \\
\hline REACT 16 & 12 countries & $\begin{array}{l}\text { Randomly } \\
\text { assigned } \\
\text { critically ill } \\
\text { patients to } \\
\text { corticosteroids } \\
\text { group or a } \\
\text { standard } \\
\text { care/placebo }\end{array}$ & 1703 & $\begin{array}{l}\text { Dexamethasone, } \\
\text { Hydrocortisone, } \\
\text { or } \\
\text { Methylprednisolo } \\
\text { ne }\end{array}$ & $\begin{array}{l}20 \mathrm{mg} / \mathrm{d} \\
\text { intravenously } \times 5 \mathrm{~d} \\
\text { and then } 10 \mathrm{mg} / \mathrm{d} \\
\text { intravenously } \times 5 \mathrm{~d} \\
6 \mathrm{mg} / \mathrm{d} \text { orally or } \\
\text { intravenously } \\
\text { Continuous } \\
\text { intravenous infusion } \\
\times 8 \mathrm{~d} \text { or } 14 \mathrm{~d}(200 \\
\mathrm{mg} / \mathrm{d} \times 4 \mathrm{~d} \text { or } 7 \mathrm{~d} \text {; } \\
100 \mathrm{mg} / \mathrm{d} \times 2 \mathrm{~d} \text { or } 4 \\
\mathrm{~d} ; 50 \mathrm{mg} / \mathrm{d} \times 2 \mathrm{~d} \text { or } 3 \\
\mathrm{~d} \\
200 \mathrm{mg} / \mathrm{d} \\
\text { intravenously } \times 7 \mathrm{~d} \\
(\text { continuous or bolus } \\
50 \mathrm{mg} \text { intravenously } \\
\text { every } 6 \mathrm{~h} \times 7 \mathrm{~d} \\
40 \mathrm{mg} \text { intravenously } \\
\text { every } 12 \mathrm{~h} \times 5 \mathrm{~d}\end{array}$ & $\begin{array}{l}\text { Varies } \\
\text { depending } \\
\text { on trials }\end{array}$ & 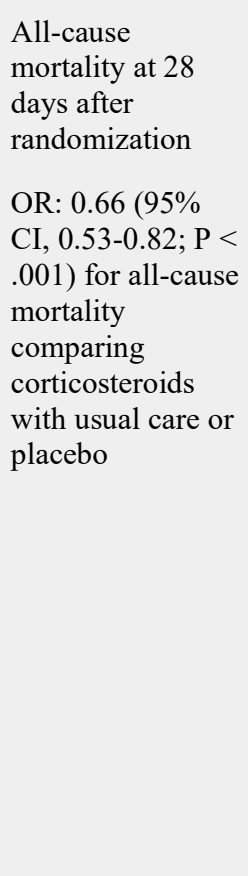 \\
\hline Recovery ${ }^{6}$ & $\begin{array}{l}\text { Multicenter, } \\
\text { randomized } \\
\text { Non blinded } \\
\text { Country: UK }\end{array}$ & $\begin{array}{l}\text { Intubation } \\
\text { Suspected or } \\
\text { confirmed } \\
\text { COVID-19 }\end{array}$ & 6425 & Dexamethasone & $\begin{array}{l}6 \mathrm{mg} / \mathrm{d} \text { orally or } \\
\text { intravenously }\end{array}$ & 5-10 days & $\begin{array}{l}\text { 28-day mortality: } \\
\text { Corticosteroid: } \\
428 / 2104 \text { (22.9\%) } \\
\text { No } \\
\text { corticosteroids: } \\
1110 / 4321 \\
(25.7 \%)\end{array}$ \\
\hline
\end{tabular}




\begin{tabular}{|c|c|c|c|c|c|c|c|}
\hline & & & & & & & $\begin{array}{l}\text { (Age-adjusted rate } \\
\text { ratio }=0.83 ; 95 \% \\
\text { CI: } 0.75-0.93 \text { ) }\end{array}$ \\
\hline CoDex ${ }^{13}$ & $\begin{array}{l}\text { Multicenter, } \\
\text { Randomized } \\
\text { Non blinded } \\
\text { Country: } \\
\text { Brazil }\end{array}$ & $\begin{array}{l}\text { Confirmed } \\
\text { COVID-19 } \\
\text { Intubation } \\
\text { Mechanical } \\
\text { Ventilated } \\
\text { Moderate to } \\
\text { severe ARDS } \\
\text { per Berlin } \\
\text { criteria } \\
\text { Onset of ARDS } \\
<48 \mathrm{~h}\end{array}$ & 256 & Dexamethasone & $\begin{array}{l}20 \mathrm{mg} / \mathrm{d} \\
\text { intravenously for } 5 \\
\text { days and then } 10 \\
\mathrm{mg} / \mathrm{d} \text { intravenously } \\
\text { for } 5 \text { days } \\
\text { Control: standard } \\
\text { care }\end{array}$ & 10 days & $\begin{array}{l}\text { 28-day mortality } \\
\text { Corticosteroids: } \\
85 / 151(56.3 \%) \\
\text { No } \\
\text { corticosteroids: } \\
\text { 91/148 }(61.5 \%) \\
\text { RR=0.86, } \\
95 \% \text { CI: } 0.64- \\
1.15\end{array}$ \\
\hline $\begin{array}{l}\text { REMAP- } \\
\text { CAP } 21\end{array}$ & $\begin{array}{l}\text { Multicenter, } \\
\text { randomized } \\
\text { Non blinded } \\
\text { Country: } \\
\text { Europe, USA, } \\
\text { Canada, } \\
\text { Australia, New } \\
\text { Zealand, Saudi } \\
\text { Arabia }\end{array}$ & $\begin{array}{l}\text { Probable or } \\
\text { confirmed } \\
\text { COVID-19 } \\
\text { Admitted to ICU } \\
\text { receiving high- } \\
\text { flow nasal } \\
\text { oxygen with } \\
\text { FIO } 2 \geq 0.4 \text { at } \geq \\
30 \mathrm{~L} / \mathrm{min}, \\
\text { noninvasive or } \\
\text { invasive } \\
\text { ventilatory } \\
\text { support, or } \\
\text { receiving } \\
\text { vasopressors }\end{array}$ & 403 & Hydrocortisone & $\begin{array}{l}\text { Intravenously fixed } \\
\text { 7-day course of } 50 \\
\text { mg or } 100 \mathrm{mg} \text { every } \\
6 \mathrm{~h}) \\
\text { OR shock-dependent } \\
\text { course of } 50 \mathrm{mg} \\
\text { every } 6 \mathrm{~h} \text { when } \\
\text { shock was clinically } \\
\text { evident) } \\
\text { Control: standard } \\
\text { care }\end{array}$ & 7 days & $\begin{array}{l}\text { 28-day mortality } \\
\text { Corticosteroids: } \\
78 / 278 . \text { No } \\
\text { corticosteroids: } \\
33 / 99 \\
\text { RR }=0.84,95 \% \\
\text { CI: } 0.60-1.18\end{array}$ \\
\hline$\underset{22}{\text { MetCOVID }}$ & $\begin{array}{l}\text { Multicenter, } \\
\text { Randomized, } \\
\text { Double- } \\
\text { blinded } \\
\text { Placebo } \\
\text { Country: } \\
\text { Brazil }\end{array}$ & $\begin{array}{l}\text { Suspicion of } \\
\text { COVID-19, } \\
\text { SpO2 } \leq 94 \% \\
\text { with room air, } \\
\text { required } \\
\text { supplementary } \\
\text { oxygen, or } \\
\text { required invasive } \\
\text { mechanical } \\
\text { ventilation }\end{array}$ & 393 & $\begin{array}{l}\text { Methylprednisolo } \\
\text { ne }\end{array}$ & $\begin{array}{l}\text { intravenous sodium } \\
\text { succinate } \\
\text { methylprednisolone } \\
0.5 \mathrm{mg} / \mathrm{kg} \text { twice } \\
\text { daily for } 5 \text { days } \\
\text { Control: saline } \\
\text { solution twice daily } \\
\text { for } 5 \text { days }\end{array}$ & & $\begin{array}{l}\text { 28-day mortality } \\
\text { methylprednisolon } \\
\text { e: } 72 / 194(37.1 \%) \\
\text { Placebo: } 76 / 199 \\
(38.2 \%) \\
\text { OR=0.91 } \\
95 \% \text { Cl: }(0.29- \\
2.87)\end{array}$ \\
\hline
\end{tabular}

Table 2 Summary of clinical trials supporting the use of corticosteroids in severely ill COVID-19 patients Abbreviations: RECOVERY, Randomized Evaluation of COVID-19 Therapy; CoDEX, COVID-19 Dexamethasone; COVID-19, coronavirus disease 2019; REMAPCAP, Randomized, Embedded, Multifactorial Adaptive Platform Trial for Community-Acquired; Methylprednisolone as Adjunctive Therapy for Patients Hospitalized with Coronavirus Disease 2019; ARDS: Acute respiratory distress syndrome; MV: Mechanical ventilation; Exp: Experimental group; OR: Odd ratio; CI: Confidence interval. 
Dinh T Calming the Storm: A review of corticosteroid use in severely ill COVID-19 patients on mechanical ventilation

\section{Conclusion}

The recommendations of corticosteroid use in severely ill mechanically ventilated patients with COVID-19 have been challenging to decipher and the efficacy of these drugs remains controversial. The pathophysiologic processes of COVID-19 infection involve various mechanisms that cause the deregulation of immune host response, resulting in systemic inflammation.

Many guidelines recommend using corticosteroids for severely ill oxygen-dependent COVID-19 patients, given their benefits of increased chance of survival and relief from lifesupportive therapy. However, there is no one specific type or dosage recommendation of corticosteroid recommended for all patients.

More high-quality studies examining and comparing the different doses, duration and classes of corticosteroids are needed to develop strong recommendations to optimize care for severely ill mechanically ventilated COVID-19 patients.

Until then, use of corticosteroids in these patients should continue to be based on the severity of illness and patientspecific factors. The optimal corticosteroids dosing and appropriate duration for COVID-19 patients still vary and need further investigation.

\section{References}

1. COVID-19 Treatment Guidelines Panel. Coronavirus Disease 2019 (COVID-19) Treatment Guidelines. National Institutes of Health. Available at https://www.covid19treatmentguidelines.nih.gov/.

2. World Health Organization. (2020). Corticosteroids for COVID-19: living guidance, 2 September 2020. World Health Organization. https://apps.who.int/iris/handle/10665/334125.

3. Annane D. Corticosteroids for COVID-19. Journal of Intensive Medicine 2021; 1(1):14-25.

4. Prescott HC, Rice TW. Corticosteroids in COVID-19 ARDS: Evidence and hope during the pandemic. JAMA 2020; 324(13):1292-1295.

5. Villar J, Ferrando C, Martínez D, et al. Dexamethasone treatment for the acute respiratory distress syndrome: a multicentre randomized controlled trial. Lancet Respir Med 2020; 8(3):267-276.

6. RECOVERY Collaborative Group, Horby P, Lim WS, Emberson JR, et al. Dexamethasone in hospitalized patients with Covid-19. N Engl J Med 2021; 384(8):693-704.
7. Williams DM. Clinical Pharmacology of Corticosteroids. Respir Care 2018; 63(6):655-670.

8. Barnes PJ. Molecular mechanisms of corticosteroids in allergic diseases. Allergy 2001; 5 6(10):928-936.

9. Khiali S, Entezari-Maleki T. Therapeutic application of corticosteroids in COVID-19: A Focus on optimum dose and duration of therapy. J Clin Pharmacol 2021; 61(9):1145-1148.

10. Johns M, George S, Taburyanskaya M, et al. A Review of the evidence for corticosteroids in COVID-19. J Pharm Pract. March 2021.

11. Ranjbar K, Moghadami M, Mirahmadizadeh A, et al. Methylprednisolone or dexamethasone, which one is superior corticosteroid in the treatment of hospitalized COVID-19 patients: a triple-blinded randomized controlled trial. BMC Infect Dis 2021; 21(1):337.

12. Pinzón MA, Ortiz S, Holguín H, et al. Dexamethasone vs methylprednisolone high dose for Covid-19 pneumonia. PLoS One 2021; 16(5):e0252057.

13. Tomazini BM, Maia IS, Cavalcanti AB, et al. Effect of dexamethasone on days alive and ventilator-free in patients with moderate or severe acute respiratory distress syndrome and COVID-19: The CoDEX Randomized Clinical Trial. JAMA 2020; 324(13):1307-1316.

14. Fernández-Cruz A, Ruiz-Antorán B, Muñoz-Gómez A, et al. A Retrospective controlled cohort study of the impact of glucocorticoid treatment in SARS-CoV-2 infection mortality. Antimicrob Agents Chemother 2020; 64(9):e01168-20.

15. COVID STEROID 2 Trial Group, Munch MW, Myatra $\mathrm{SN}$, Vijayaraghavan BKT, et al. Effect of $12 \mathrm{mg}$ vs $6 \mathrm{mg}$ of dexamethasone on the number of days alive without life support in adults with COVID-19 and severe hypoxemia: The COVID STEROID 2 Randomized Trial. JAMA 2021; 326(18):1807-1817.

16. WHO Rapid Evidence Appraisal for COVID-19 Therapies (REACT) Working Group. Association between administration of systemic corticosteroids and mortality among critically ill patients with COVID-19: A Meta-analysis. JAMA 2020; 324(13):1330-1341.

17. Granholm A, Munch MW, Myatra SN, et al. Dexamethasone $12 \mathrm{mg}$ versus $6 \mathrm{mg}$ for patients with COVID19 and severe hypoxaemia: a pre-planned, secondary Bayesian analysis of the COVID STEROID 2 trial. Intensive Care Med 2021; 1-11. 
Dinh T Calming the Storm: A review of corticosteroid use in severely ill COVID-19 patients on mechanical ventilation

18. Annane D, Pastores SM, Rochwerg B, et al. Guidelines for the diagnosis and management of critical illness-related corticosteroid insufficiency (CIRCI) in critically ill patients (part I): Society of Critical Care Medicine (SCCM) and European Society of Intensive Care Medicine (ESICM) 2017. Crit Care Med 2017; 45(12):2078-2088.

19. Dunn TE, Ludwig EA, Slaughter RL, et al. Pharmacokinetics and pharmacodynamics of methylprednisolone in obesity. Clin Pharmacol Ther 1991; 49(5):536-549.

20. Erstad BL, Barletta JF. Drug dosing in the critically ill obese patient: a focus on medications for hemodynamic support and prophylaxis. Crit Care 2021; 25(1):77.

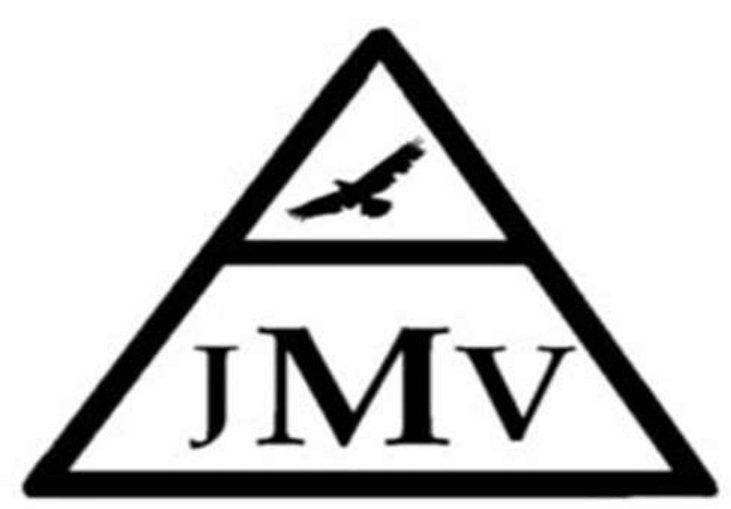

Journal of Mechanical Ventilation

\section{Submit a manuscript}

https://www.journalmechanicalventilation
.com/submit-a-manuscript/
21. Angus DC, Derde L, Al-Beidh F, et al. Effect of hydrocortisone on mortality and organ support in patients with severe COVID-19: The REMAP-CAP COVID-19 Corticosteroid Domain Randomized Clinical Trial. JAMA 2020; 324(13):1317-1329.

22. Jeronimo CMP, Farias MEL, Val FFA, et al. Methylprednisolone as adjunctive therapy for patients hospitalized with coronavirus disease 2019 (COVID-19; Metcovid): A Randomized, Double-blind, Phase IIb, Placebocontrolled Trial. Clin Infect Dis 2021; 72(9):e373-e381.

23. Albani F, Fusina F, Granato E, et al. Corticosteroid treatment has no effect on hospital mortality in COVID-19 patients. Sci Rep 2021; 11(1):1015.

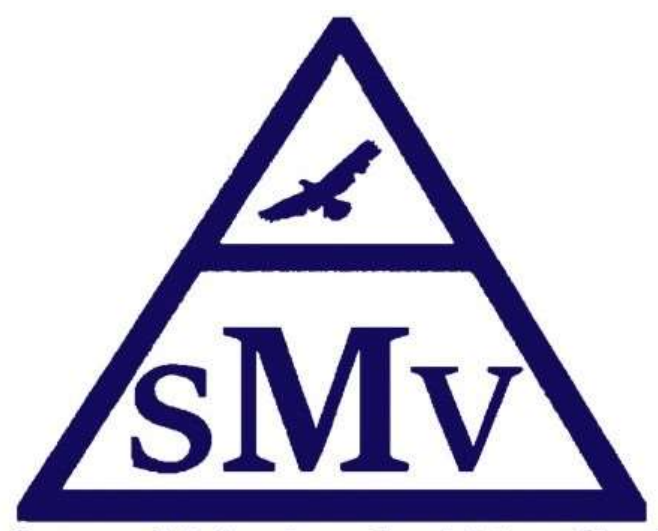

Society of Mechanical Ventilation

https://societymechanicalventilation.org /membership/ 